\title{
The Determinants of Targeted Poverty Alleviation Expenditure for Chinese Listed Firms: A Regional Politicalized CSR Perspective
}

\author{
Xiaobei Huang* and Tiantian Song \\ North China University of Technology, Shijingshan District Beijing, P.R. China 100144 \\ ${ }^{*}$ Corresponding author. Email: hberyl@163.com
}

\begin{abstract}
Chinese listed firms played an important role in the poverty alleviation battle. Based on the poverty alleviation data release by Chinese listed firms in 2016 and 2017, this paper empirically exam the determinants of poverty alleviation expenditure for listed firms from the three perspectives of political pressure, CSR performance, and signaling motivation. We find that SOEs, larger firms, firms with better CSR performance, and higher demand for communication with external stakeholders demonstrate higher levels of TPA investments. We further find SOEs' TPA investing is mainly affected by political pressure, especially for SOEs from poverty-stricken regions. But the TPA expenditure of private listed firms is more affected by CSR performance. The overall results suggesting that the TPA practice in China is a form of regional politicalized corporate social responsibility.
\end{abstract}

Keywords: Targeted poverty alleviation, Targeted poverty alleviation expenditure, Corporate social responsibility.

\section{INTRODUCTION}

China has achieved tremendous success in poverty alleviation in the past decades, especially under the guidance of targeted poverty alleviation strategy (referred to as TPA thereafter) which proposed by Chinese President Xi Jinping in 2013.The determinants of CSR and corporate philanthropic has been well documented in extant literature(Ma and Parish,2006; Qu, 2007;Borghesi et al., 2014;Tan and Tang,2016). However, we know little about how firm's behavior in poverty alleviation under the explicit guidance from government in emerging market. It is more political orientated compare with regular CSR activities, and we can expect that listed firms investing in TPA may drive by more complicated factors than CSR.

In this paper, we discuss the determinants of TPA investments for Chinese listed firms from different perspectives, using the hand-collected TPA data from 2016 to 2017. Political pressure has great impact on a firm's TPA investments. State-owned enterprises (referred to as SOEs thereafter) invest more compare to Non-SOEs, and the involvement of party membership in corporate governance will further promote the investment for SOEs, which is consistent with the political-oriented feature of TPA. TPA investment is associated with a firm's CSR performance; firms with better CSR performance will also invest more in TPA project. Listed firms also have the incentive to impress external stakeholders by disclosing TPA investment information.

However, the motivations varied when firms under different local poverty alleviation pressure. For firms come from poverty-stricken regions, their TPA investments are mainly driven by political factors, suggesting that local government may transfer the poverty alleviation pressure to local SOEs. In less poverty regions, there is no significant difference in TPA investments for SOEs and Non-SOEs, Non-SOEs are more likely to invest more to get political resources and which is consistent with their traditional CSR activities.

\section{INSTITUTIONAL BACKGROUND AND LITERATURE REVIEW}

To accomplish the goal of 2020 to lift all of the people out of poverty, President Xi put forward targeted 
poverty alleviation strategy, which encourages market force to join the battle against poverty. The capital market also encourages listed firms to make contribution to TPA. In December 2016, Chinese stock exchanges started to encourage listed firms including TPA information in annual report. Firms are expected to fill in a formed table in the "Important Events" section of the annual report which contains the information of the annual summary, the specific type TPA projects(The eight specific TPA project includes industrial development, employment transfer, education, health, ecological protection, bottom-up protection, social poverty alleviation, and other projects .), the quantified TPA input and the corresponding output (the number of people lifted out of poverty) for each TPA type, the awards for TPA work and the follow-up plan. Meanwhile, listed firms are encouraged to release such information if they issue CSR reports. From 2016 to 2017, there are 1,413 listed firms disclose TPA information in the annual report or CSR report, accounts for over $30 \%$ of total Chinese A-share listed firms.

The engagement of firms can accelerate the process of poverty alleviation (Zhong, 2018), it also benefits firms in several ways. From the perspective of stakeholder theory, firms invest in CSR or make donations can improve reputation, which can further attract clients, and improve investment efficiency and firm's performance (Benlemlih and Bitar,2018). As a complement of financial information, CSR information can reduce information asymmetry, lower the cost of capital and agency cost, and increase firm value (Dhaliwal et al., 2012, 2014).

As the largest emerging market, Chinese government is one of the most critical stakeholders for Chinese listed firms. Chinese listed firms have the incentives to impress government and establish the political connection (Chen, 2016), so as to get more political resources by taking social responsibility, which is called "reciprocity between government and enterprise".

\section{HYPOTHESIS}

Based on extant literature and Chinese TPA practice, we discuss the determinants of a firm's TPA investments in the following three aspects.

\subsection{Political Pressure}

As one of the "three critical battles" in China, the goal of TPA is to "eliminate absolute poverty, ensuring that all poverty-stricken counties get rid of poverty by 2020". For a long time, China's state-owned enterprises have undertaken policy burdens such as safeguarding public interests and employment. Under the TPA strategy, the central government has strengthened the responsibilities of SOEs, requiring them to help poverty-stricken people get rid of poverty through various methods such as developing industries, docking the market, and relocating employees. At the same time, TPA performance is taken as an essential indicator for evaluating the performance of SOEs, it is also crucial for political promotion of state-owned enterprise managers. TPA is more like a political task for Chinese SOEs (Irina et al., 2018). In contrast, there is no specific requirement for private firms; the political pressure for those firms is relatively low. Therefore, we argue that SOEs invest more in TPA than private firms.

H1a Compared with private firms, SOEs invest more in TPA.

In the practice, TPA decision is an essential part of the "party building" for SOEs and it is carried out under the leadership of party committee. Although Chinese state-owned enterprise reforms emphasize "separation of government and enterprise," party committee can still intervene in business decision through "two-way entry and cross-serving positions" for SOEs. The poverty alleviation pressure and the incentive for personal political promotion will stimulate the party committee member increases the TPA investments. Therefore, we expect that the party committee members cross-serving with other positions which can impact business decision can promote TPA investments, and propose the following hypothesis:

H1b The intervention of Party Committee is associate with higher TPA investments for SOEs.

On the other hand, Chinese private firms have the incentive to obtain political legitimacy by "political contributions"(Zhao,2012), which can help them get political resources such as credit, government subsidies, and investment opportunities, this reciprocity especially benefit political connected firms (Shen et al., 2011). The political orientation of targeted poverty alleviation provides a more direct and targeted channel for private firms to strengthen political connections and obtain policy resources to achieve "reciprocity between government and enterprises." So, we expect that if a private firm is politically connected, its TPA investments will be more vigorous.

H1c Political-connection stimulates private listed companies to invest more in TPA.

\subsection{Corporate Social Responsibility Performance}

As Carroll's CSR pyramid (1979) shows, elimination of poverty is ranked as the top of a firm's corporate social responsibility. Despite the political feature of TPA, corporate philanthropy is still one of the important aspects of corporate social responsibility. We can expect that, if a firm performer well in CSR, the spillover effect of CSR implementation will associate with higher TPA investing. 
H2 TPA investment is positively associated with TPA investments.

\subsection{Signaling Factors}

Apart from political legitimacy, the engagement of CSR and corporate philanthropy can generate "advertising effects" (Schiller,1988; Godfrey,2005), which can help firms increase sales, reputation, and firm value. Therefore, CSR and corporate philanthropy can be served as self-interest tools for firms to impress market participants (Zhang et al., 2010; Chen et al., 2016).

TPA is one of the "three critical battles" in China; firms engaged in TPA do not only doing the political "good", but also bring public welfare by lifting people out of the poverty. We can expect that, if a firm wants to impress external stakeholders by releasing the signal of "doing good", it will invest more in TPA. Given the above analysis, we propose the hypothesis:

$\mathrm{H} 3 \mathrm{a}$ : The stronger the willingness of a listed firm to communicate with the market, the higher they will invest in TPA.

From the perspective of information disclosure, TPA information is mainly transmitted through annual reports and CSR report, which will have a direct impact on capital market stakeholders. Listed firms are monitored by market participators such as analysts; TPA investment information can lower the information asymmetry between them. It is also a good way by signaling promising investment opportunities and performance from TPA investments to the stakeholders to improve a firm's market value. Thus, it leads to the following hypothesis:

$\mathrm{H} 3 \mathrm{~b}$ : The more a listed firm is monitored by capital market stakeholders, the higher the level of the poverty alleviation investments.

\section{RESEARCH DESIGN}

\subsection{Data}

We hand-collected TPA information from the annual report and CSR report from 2016 to 2017, since listed firms are encouraged to disclose TPA information from 2016. Among the total 3,406 A-share listed-years firm during this period, there are 1,413 firm-years disclose TPA information and 1,013 of them have quantitative TPA input information, which accounts for less than $30 \%$ of the total listed firm-years. Given the TPA inputs for the financial industry are usually measured by poverty alleviation loan/issuance, which are different from other industries, we exclude the firms from financial industry. We also exclude losses firms and firms with missing value and get 2,268 firm-years as our final sample. For the empirical tests, we hand collected the data of the poverty-stricken area and political connections. The CSR scores come from Hexun Rating; other financial data come from WIND database, which has been wildly used in Chinese listed firms' research.

\subsection{Variables}

We are aiming to investigate the determinants of TPA input, given that there are only $30 \%$ listed firms have TPA input data, most of the sample firms are clustered at zero, we use Tobit model to estimate how different factors affect a firm's TPA investments.

$F P T R=\beta_{0}+\beta_{1}$ Political $+\beta_{2} C S R+\beta_{3}$ Signal $+\beta_{i}$ Controls $+\varepsilon$ Model (1)

Our dependent variable is FPTR, which is measured by the total TPA quantitative input which including monetary expenditure and goods converted into money, scaled by the sales for year $t$ to eliminate the size effect.

We set three variables to capture the political factors, SOE is 1 if a firm is directly owned or ultimately controlled by the government and 0 otherwise. For the sample of state-owned enterprises, set ZL as a party intervention variable, which is defined as if the party committee member of a state-owned enterprise also serves on the company's board of directors, the board of supervisors or management, then the party is considered to be involved in business decision, ZL will be coded as 1 , and 0 otherwise. For private firms, if a firm's ultimately controller is deputy to National People's Congress or is the member of National Committee of the Chinese People's Political Consultative Conference (CPPCC), or if the managers and board members used to have a position in government, it will be treated as political connected and the variable PC will be 1 , and 0 otherwise.

We use Hexun social responsibility rating data to capture corporate responsibility performance. We use three variables to capture the willingness of a firm to communicate with external stakeholders by TPA information disclosing. The existing research suggests that the higher the intensity of corporate advertising, the stronger their willingness to communicate with the market (Borghesi et al., 2014). We use ADV as the ratio of a company's selling expenses to its sales to capture the advertising intensity. Analysts and institutional investors are selected as proxy variables of concerns from external stakeholders in the capital market, where the variable $\mathrm{AF}$ is defined as the size of analysts who provided earnings estimates for the previous year. IOpct is defined as the shareholding percentage of institutional investors.

Based on the motivation and constraint of corporate TPA investments, we include a set of control variables: (1) firm size (Size), which proxies for political and reputation costs in China, (2) cash flow volatility (StdCFO), which captures the stability of cash flows, (3) 
ROA, which reflects the firm's profitability,(4) redundant resources (Slack), which measures the redundant resources that available for TPA investing, (5) corporate governance (Boardsize), (6) Tobin's Q (TQ), which captures the firm's growth prospect,(7) debt size(LEV), which captures the firm's financing ability, (8) industry competition (Competition), which proxies for proprietary disclosure costs. Also, in order to alleviate endogenous problems, the CSR and signaling variables were lagging for one year, and all continuous variables are winsorized at $1 \%$ and $99 \%$ in the regression.

\section{EMPIRICAL RESULTS}

\subsection{Main Results}

Table 1 presents the estimation results of Model (1). As predicted in $\mathrm{H} 1 \mathrm{a}, \mathrm{SOE}$ is significantly positive in both estimations, indicating that compared with private firms, SOEs have invested more in poverty alleviation. ZL also has a positive coefficient in Equation (2), which means when party commission member intervenes corporate decision, the SOEs will invest more, $\mathrm{H} 1 \mathrm{~b}$ has confirmed. For the private-firm sample regression in Equation (3), the coefficient of PC is positive, but not significant, indicating that the political connection of private firm has not significantly affected TPA investments.

Equation(4) shows the results of CSR factor, as predicted in H2, CSR is significantly positive with TPA investments, which means that the better of a firm's CSR performance, the more it will invest. Equations (5) and (6) are signaling factors regressions. The coefficient of ADV is positively associated with TPA investments, which means firms will take advantage of TPA investments to improve reputation. Also, both AF and IOpct are significantly positive, indicating that the higher attention of the external stakeholders a firm has, the higher TPA investments the firm will make, and H3a and $\mathrm{H} 3 \mathrm{~b}$ are both approved. Equation (7) incorporates the above factors into one regression, the results remain unchanged.

Table 1. Main Regressions Results

\begin{tabular}{|c|c|c|c|c|c|c|c|}
\hline & (1) & (2) & (3) & (4) & (5) & (6) & (7) \\
\hline & \multicolumn{3}{|c|}{ Political Pressure } & CSR & \multicolumn{2}{|c|}{ Signaling Factors } & \\
\hline & Full sample & SOE & Non-SOE & Full sample & Full sample & Full sample & Full sample \\
\hline \multirow[t]{2}{*}{$S O E$} & $0.018^{* *}$ & & & & & & $0.018^{*}$ \\
\hline & (1.97) & & & & & & (1.90) \\
\hline \multirow[t]{2}{*}{$Z L$} & & $0.020^{*}$ & & & & & \\
\hline & & (1.96) & & & & & \\
\hline \multirow[t]{2}{*}{$P C$} & & & 0.023 & & & & \\
\hline & & & $(0.86)$ & & & & \\
\hline \multirow[t]{2}{*}{$C S R$} & & & & $0.013 * * *$ & & & $0.011 * *$ \\
\hline & & & & (3.01) & & & (2.53) \\
\hline \multirow[t]{2}{*}{$A D V$} & & & & & $0.101 *$ & & $0.106^{*}$ \\
\hline & & & & & $(1.78)$ & & $(1.84)$ \\
\hline \multirow[t]{2}{*}{$A F$} & & & & & & $0.009^{*}$ & $0.008^{*}$ \\
\hline & & & & & & (1.86) & (1.66) \\
\hline \multirow[t]{2}{*}{$I O p c t$} & & & & & & $0.038 * *$ & $0.031 *$ \\
\hline & & & & & & $(2.45)$ & (1.92) \\
\hline \multicolumn{8}{|l|}{ Controls } \\
\hline \multirow[t]{2}{*}{ Constant } & $-0.167 * *$ & $-0.250 * * *$ & -0.037 & $-0.145^{* *}$ & -0.358 & $-0.155^{* *}$ & 0.058 \\
\hline & $(-2.31)$ & $(-3.17)$ & $(-0.21)$ & $(-2.00)$ & $(-0.47)$ & $(-2.11)$ & $(0.07)$ \\
\hline Industry effects & Yes & Yes & Yes & Yes & Yes & Yes & Yes \\
\hline$N$ & 2268 & 1387 & 881 & 2268 & 2268 & 2268 & 2268 \\
\hline Pseudo $R^{2}$ & 0.275 & 0.625 & 0.179 & 0.282 & 0.274 & 0.282 & 0.300 \\
\hline
\end{tabular}


Table 2. Cross-sectional Regression Results

\begin{tabular}{|c|c|c|c|c|c|c|}
\hline & $(1)$ & (2) & (3) & (4) & $(5)$ & (6) \\
\hline & \multicolumn{3}{|c|}{ Poverty regions } & \multicolumn{3}{|c|}{ Less poverty regions } \\
\hline & Full Sample & SOEs & Non-SOEs & Full Sample & SOEs & Non-SOEs \\
\hline \multirow[t]{2}{*}{$S O E$} & $0.046^{* * *}$ & & & -0.009 & & \\
\hline & $(3.22)$ & & & $(-0.76)$ & & \\
\hline \multirow[t]{2}{*}{$Z L$} & & $0.041 * *$ & & & 0.004 & \\
\hline & & $(2.06)$ & & & $(0.43)$ & \\
\hline \multirow[t]{2}{*}{$P C$} & & & -0.005 & & & $0.074 *$ \\
\hline & & & $(-0.14)$ & & & $(1.78)$ \\
\hline \multirow[t]{2}{*}{ CSR } & 0.011 & 0.002 & 0.022 & $0.015 * * *$ & 0.005 & $0.040 * *$ \\
\hline & $(1.58)$ & $(0.26)$ & $(1.46)$ & $(2.67)$ & $(1.31)$ & $(2.12)$ \\
\hline \multirow[t]{2}{*}{ Competiton } & 0.109 & -1.234 & 2.673 & -0.661 & -0.233 & -3.945 \\
\hline & $(0.06)$ & $(-0.55)$ & $(0.93)$ & $(-0.58)$ & $(-0.29)$ & $(-0.89)$ \\
\hline \multirow[t]{2}{*}{$A D V$} & $0.165 * *$ & -0.036 & $0.288^{* *}$ & -0.002 & 0.026 & -0.061 \\
\hline & $(2.00)$ & $(-0.29)$ & $(2.40)$ & $(-0.02)$ & $(0.36)$ & $(-0.30)$ \\
\hline \multirow[t]{2}{*}{$A F$} & 0.003 & 0.006 & 0.002 & 0.006 & 0.008 & 0.008 \\
\hline & $(0.43)$ & $(0.71)$ & $(0.11)$ & $(0.84)$ & $(1.55)$ & $(0.39)$ \\
\hline \multirow[t]{2}{*}{ IOpct } & 0.037 & 0.045 & 0.021 & 0.03 & $0.028 *$ & 0.030 \\
\hline & $(1.46)$ & $(1.53)$ & $(0.41)$ & $(1.44)$ & $(1.90)$ & $(0.45)$ \\
\hline \multirow[t]{2}{*}{ Constant } & -0.282 & 0.608 & -1.943 & 0.32 & 0.081 & 1.896 \\
\hline & $(-0.20)$ & $(0.33)$ & $(-0.81)$ & -0.34 & $(0.12)$ & $(0.02)$ \\
\hline Industry effects & Yes & Yes & Yes & Yes & Yes & Yes \\
\hline$N$ & 1026 & 636 & 390 & 1242 & 751 & 491 \\
\hline Pseudo $R^{2}$ & 0.398 & 0.522 & 0.545 & 0.349 & 0.521 & 0.265 \\
\hline
\end{tabular}

\subsection{Cross-sectional Analysis}

At present, the number of poverty people and poverty-stricken towns are distributed unequally in China, for instance, there are 47 poverty-stricken towns in Guizhou Province when the number is zero in Zhejing Province. To achieve the TPA goal in 2020, local governments with higher poverty alleviation pressure have the incentive to push local listed firms to invest more in TPA project, therefore we expect the TPA investments of listed firms from different provinces will be affected by regional poverty alleviation pressure.To test this conjecture, we divide our sample into two groups based on the TPA pressure they may have. We repeat the regression tests in the two sub-samples and the results are shown in Table 2.

Equations (1) and (4) are full-sample regressions, it can be seen that SOE is significantly positive only in the poverty sample, SOEs from more poverty-stricken areas are investing more than Non-SOEs, and there are no significant differences in sub-sample from less poverty regions .This result is consistent with our conjecture, local poverty alleviation pressure will stimulate TPA investments for SOEs.
CSR is only significantly positive in the sample from less poverty regions and not significant in the sample from more poverty-stricken areas, which indicating that in the absence of local poverty alleviation pressure,TPA can be still regarded as a new content of social responsibility for listed firms. We further compare SOEs and Non-SOEs in the two groups. In Equations (2) and (5) the coefficient of ZL is only significantly positive in the sample from poverty areas, indicating that party intervention in corporate governance can significantly increase the SOEs' TPA investments, but it has limited impact on SOEs from less poverty regions. Signaling factors have no significant impact on TPA investments for these SOEs. The results are consistent with the foregoing analysis, suggesting political factors are more effective in the poverty regions, TPA can be viewed as political tasks for SOEs from these regions rather than CSR.

In Equations (3) and (6), the coefficients of PC and CSR are significantly positive only in less poverty region group, it shows that in places with less poverty alleviation pressure, TPA investments of private firms are mainly driven by their consistent CSR performance, and consistent with CSR literature, private firms have the incentive to maintain and enhance political 
connection through TPA investments. In the poverty-stricken group, the investment of private firm is significantly lower than that of SOEs; moreover, neither the political connection nor the CSR performance has significant impacts on TPA investments. One possible reason is that government resources in poverty regions are limited, private firms have lower expectations for "reciprocity between government and enterprises" through TPA investments.

\section{CONCLUSION}

This paper investigates the determinants of targeted poverty alleviation investment for Chinese listed firms. We find that less than $30 \%$ disclose the quantitative targeted poverty alleviation investment information after regulators encourage listed firms to contribute to the national poverty alleviation strategy. Using Tobit regression, we find that political pressures and CSR performance can affect a firm's TPA expenditure, but the impacts are complicated when firms under different poverty alleviation pressure. To be specific, SOEs invest more than private firms, the participation of party committees in business can further increase TPA expenditure for SOEs. But political pressure only impacts SOEs that come from poverty-stricken regions, suggesting TPA is a regional political task for SOEs. For private firms, since there is no direct requirement for them, TPA investments still associate with their CSR performance, TPA acting as a new branch of CSR. To sum up, the Chinese listed firm participates in TPA can be regarded as regional politicalized corporate social responsibility.

\section{ACKNOWLEDGMENTS}

Xiaobei Huang thanks the support of National Natural Science Foundation of China (71602004), the Social Science Foundation of Beijing (19GLC059), and the Basic Research Funding of Beijing Municipal Education Commission. All errors are our own.

\section{REFERENCES}

[1] Benlemlih M, Bitar M. Corporate Social Responsibility and Investment Efficiency. Journal of Business Ethics, 2018, 148(3):647-671.

[2] Borghesi R, Houston JF, Naranjo A. Corporate socially responsible investments: CEO altruism, reputation, and shareholder interests [J]. Journal of Corporate Finance, 2014, 26:164-181.

[3] Chen J, Dong W, Tong J, et al. Corporate Philanthropy and Tunneling: Evidence from China. Journal of Business Ethics, 2016(1):1-23.

[4] Dhaliwal, D., Li, O., Tsang, A., Yang, Y. (2014). Corporate social responsibility disclosure and the cost of equity capital, The roles of stakeholder orientation and financial transparency, Journal of Accounting and Public Policy, 33 (4), 328-355.

[5] Godfrey PC. The Relationship between Corporate Philanthropy and Shareholder Wealth: A Risk Management Perspective. Academy of Management Review, 2015, 30(4), 777-798. 